\title{
HORMONE-INDUCED REARRANGEMENT OF LOCUST HAEMOLYMPH LIPOPROTEINS
}

\author{
THE INVOLVEMENT OF GLYCOPROTEIN $\mathrm{C}_{2}$
}

\author{
D. J. Van der Horst, J. M. Van Doorn and A. M. Th. Beenakkers \\ Laboratory of Chemical Animal Physiology, State University of Utrecht, 8 Padualaan, 3508 TB Utrecht,
} The Netherlands

(Received 9 December 1983)

\begin{abstract}
Formation of lipoprotein $\mathrm{A}^{+}$and elevation of lipoprotein fraction $\mathrm{O}$ in locust (Locusta migratoria migratorioides) haemolymph as induced by adipokinetic hormone (AKH) includes the participation of non-lipid carrying proteins (fraction $\mathrm{C}$ ), which was examined in more detail. By using gel filtration chromatography, the rather heterogenous $\mathrm{C}$-proteins were resolved into three protein fractions, only one of which $\left(\mathrm{C}_{2}\right)$ appeared to be actually involved in the lipoprotein reassociation. The changes in amino acid composition of the elevated lipoprotein fractions as compared with those from the lipoproteins in the resting situation are accounted for by the contribution of the rather specific amino acid composition of this $\mathrm{C}_{2}$-fraction. Polyacrylamide gel electrophoresis (PAGE) indicates that the $\mathrm{C}_{2}$-protein is migrating as only one band; SDS-PAGE revealed that the $\mathrm{C}_{2}$-protein consists of one single polypeptide chain with an approximate molecular weight of 20,000. This chain is also recovered in the subunit structure of the lipoprotein fractions induced by $\mathrm{AKH}$-injection $\left(\mathrm{A}^{+}, \mathrm{O}_{\mathrm{AKH}}\right)$ in contrast with that of the lipoprotein fractions in resting haemolymph. Unlike the other $C$-proteins, protein $\mathrm{C}_{2}$ displayed immunoreactivity with antiserum raised against lipoprotein $\mathrm{A}^{+}$. From carbohydrate analyses, $\mathrm{C}_{2}$ appeared to be a glycoprotein containing approx. $12.5 \%$ carbohydrate. In vivo pilot studies on the dynamics of $\mathrm{C}_{2}$-proteins using ${ }^{3} \mathrm{H}$-labelled glycoprotein $\mathrm{C}_{2}$ gave evidence for the incorporation of radiolabel into both $\mathrm{A}^{+}$and $\mathrm{O}_{\mathrm{AKH}}$. Possible functions of the involvement of the glycoprotein to $\mathrm{A}^{+}$formation are discussed.
\end{abstract}

Key Word Index: Locusta migratoria migratorioides, lipoproteins, lipid transport, energy supply, adipokinetic hormone, glycoprotein

\section{INTRODUCTION}

One of the major functions of haemolymph lipoproteins in adult locusts is to supply lipids to the working flight muscles. Characteristically, flightinduced stimulation of lipid mobilization from the fat body is predominantly controlled by adipokinetic hormone (AKH) and manifested by a considerable increase in the level of haemolymph diacylglycerol, which is transported associated with carrier lipoproteins to the flight muscles (for reviews, see Beenakkers et al., 1981a, b, 1984a, b). In resting locusts, haemolymph diacylglycerol is transported by lipoprotein fraction $A_{\text {yellow }}$ which is eluted by gel filtration chromatography in addition to lipoprotein fraction $O$ which is recovered in the void volume. However, promotion of lipid mobilization as induced by flight or injection of AKH is attended by the formation of a "new" lipoprotein of higher molecular weight $\left(\mathrm{A}^{+}\right)$along with an increase in both lipid and protein contents of fraction $\mathrm{O}$ (Mwangi and Goldsworthy, 1977; Van der Horst et al., 1979). These changes in lipoproteins originate from combinations of two existing haemolymph protein components, e.g. lipoprotein $\mathbf{A}_{\text {yellow }}$ and non-lipid containing proteins (fraction $\mathrm{C}$ ), as was concluded from both immunological evidence and experiments using radioiodinated lipoprotein $\mathbf{A}_{\text {yellow }}$ or protein fraction $\mathrm{C}$ (Van der Horst et al., 1981a,b). The resulting lipoprotein fractions display a high capacity for diacylglycerol binding which accounts for the progressive turnover of diacylglycerol during flight (Van der Horst et al., 1978, 1979). Hence this lipoprotein rearrangement is of vital importance. Since virtually nothing is known about the mechanism of this arrangement, which is particularly true for the participation of the heterogenous protein fraction $C$, the present paper explores some biochemical features of the changes in the lipoproteins and especially the $\mathrm{C}$-proteins, during the action of AKH.

\section{MATERIALS AND METHODS}

\section{Insect handling}

Locusta migratoria migratorioides were taken from the colony reared $a b$ ovo in the laboratory under crowded conditions as described previously (Van der Horst et al., 1978). Adult male insects (12 days after the imaginal ecdysis) were used in all experiments. Synthetic adipokinetic hormone (AKH) (Peninsula Laboratories, San Carlos, California), prepared as a stock solution in absolute methanol, was diluted with water and injected at a dosage of $10 \mathrm{pmol}$ in a volume of $10 \mu \mathrm{l} /$ locust to induce elevation of haemolymph diacylglycerol levels. Haemolymph was collected from resting and AKH-injected ( 90 min after injection) insects from a puncture in the ventral neck membrane made with a Hamilton microsyringe. Samples of $25 \mu$ 1/locust were immediately pooled in ice-cooled centrifugation tubes containing $1-2 \mathrm{ml}$ of buffer (pH 7.5) consisting of $130 \mathrm{mM} \mathrm{NaCl}$, $5 \mathrm{mM} \mathrm{KCl}, 1.9 \mathrm{mM} \mathrm{NaH}_{2} \mathrm{PO}_{4}$ and $1.7 \mathrm{mM} \mathrm{KH}_{2} \mathrm{PO}_{4}$, to which $2.5 \mathrm{mM}$ glutathione and $0.02 \% \mathrm{NaN}_{3}$ were added. Pooled haemolymph samples (final dilution, $50 \%$; final volumes $2-4 \mathrm{ml}$ ) were centrifuged at $12,000 \mathrm{~g}$ for $2 \mathrm{~min}$ at 
$4^{\circ} \mathrm{C}$ to remove haemocytes, yielding clear, unclotted sera which were used directly.

\section{Isolation of haemolymph proteins}

Gel permeation chromatography of freshly prepared haemolymph samples (2-4 ml) was performed on glass columns $(200 \times 1.6 \mathrm{~cm}$ i.d.) packed with Ultrogel AcA 22 (LKB Ltd) as described earlier (Van der Horst et al., 1979). Except for the absence of glutathione, the buffer used for elution of proteins was as described above. The eluates containing lipoprotein fractions $\mathrm{O}$ and $\mathrm{A}_{\text {yellow }}$ from resting haemolymph and those containing $\mathrm{O}_{\mathrm{AKH}}$ and $\mathrm{A}^{+}$from elevated haemolymph were concentrated by ultrafiltration using an Amicon Cell $(50 \mathrm{ml})$ with a PM 10 membrane as described before (Van der Horst et al., 1981b). For isolation of the various $\mathrm{C}$-proteins before and after hormone injection, the eluates containing the protein fractions $B$ and $C$ (which due to the fractionation range of the column cannot be resolved completely) were pooled and concentrated as indicated above except for the use of YM 2 membranes and subjected to gel filtration chromatography on Sephadex G-75 (Pharmacia) packed into glass columns $(200 \times 1.6 \mathrm{~cm}$ i.d. $)$. Alternatively, C-proteins were isolated directly from fresh haemolymph samples by chromatography on Sephacryl S-200 Superfine (Pharmacia) columns $(200 \times 1.6 \mathrm{~cm}$ i.d.). Elution buffer was as above. Separated B- and C-protein fractions obtained by either method were concentrated by ultrafiltration using YM 2 membranes. In view of the observed susceptibility to degradation of one of the isolated C-protein fractions on storage for more than a few days at $4^{\circ} \mathrm{C}$ in the dark, $10 \mu \mathrm{M}$ of the serine protease inhibitor phenylmethylsulphonyl fluoride (Sigma) was included where indicated.

\section{Amino acid compositions}

Amino acid compositions of lipoprotein and protein fractions were analyzed after hydrolysis of about $5 \mathrm{mg}$ samples in $6 \mathrm{M} \mathrm{HCl}$ at $110^{\circ} \mathrm{C}$ in vacuo for 24,48 and $72 \mathrm{hr}$ with a Biocal analyzer (LKB), using chromax-11 resins and lithium citrate buffers according to Benson et al. (1967). Lipoprotein fractions were delipidated with chloroformmethanol (Bligh and Dyer, 1959) prior to hydrolysis. Lipoprotein $A_{\text {yellow }}$ was purified from contaminating protein $A_{\text {blue }}$ by chromatography on a glass column $(25 \times 1.6 \mathrm{~cm}$ i.d. $)$ packed with Cellex D (Bio-Rad), using $0.05 \mathrm{M} \mathrm{NaH}_{2} \mathrm{PO}_{4}$ (pH 6.3) for elution of $\mathrm{A}_{\text {blue }}$ followed by $0.10 \mathrm{M} \mathrm{NaH}_{2} \mathrm{PO}_{4}$ $+0.5 \mathrm{M} \mathrm{KCl}\left(\mathrm{pH} \mathrm{6.3)}\right.$ for isolation of $\mathrm{A}_{\text {yellow }}$, which was concentrated by ultrafiltration (PM 10 membrane).

\section{Electrophoresis}

Polyacrylamide gel electrophoresis (PAGE) of locust protein fractions was carried out on $7.5 \%$ gels in Tris $(0.045 \mathrm{M})$-glycine $(0.100 \mathrm{M})$ buffer at $\mathrm{pH} 8.9$, using the LKB 2117 Multiphore horizontal system. Since particularly C-protein components were not detected with the generally used Coomassie Brilliant Blue R 250 dye, gels were stained for protein with Amido black $10 \mathrm{~B}$.

ro analyze the subunit structure, following denaturation in $1 \%$ of sodium dodecyl sulphate (SDS), samples of the protein and lipoprotein fractions were separated by SDS-PAGE on $12.5 \%$ gels in a modified discontinuous buffer system containing $0.1 \%$ SDS according to Laemmli and Favre (1973), using the equipment described above. Prior to denaturation, lipoproteins were delipidated with alcohol-ether according to the method of Shore and Shore (1962). Protein bands were stained with Amido black $10 \mathrm{~B}$. For calculation of molecular weights, protein markers of known molecular weight (Electrophoresis Calibration Kit; Pharmacia) were used.

\section{Protein determination}

Initially protein contents of all chromatography samples were routinely measured after staining with Coomassie
Brilliant Blue G250 according to Bradford (1976). As, however, in contrast to other proteins, intensity of staining of the C-proteins appeared to be too low to be used for quantification, the Lowry method as modified by Schacterle and Pollack (1973) was adopted.

\section{Determination of carbohydrates}

Carbohydrate content of glycoproteins was assayed colorimetrically with phenol-sulphuric acid after the method of Dubois et al. (1956).

\section{Immunological procedures}

The preparation of specific antiserum against lipoprotein $\mathrm{A}^{+}$and the conditions for the Ouchterlony double diffusion test were described in a previous paper (Van der Horst $e t$ al., 1981a).

\section{Protein labelling}

Individual C-protein fractions (approx. $1 \mathrm{mg}$ ) isolated by gel filtration chromatography on Sephacryl S-200 Superfine as described above were taken up in $100 \mu 10.1 \mathrm{M}$ borate buffer $(\mathrm{pH} 8.5)$ and reacted for $15 \mathrm{~min}$ at $0{ }^{\circ} \mathrm{C}$ with $0.5 \mathrm{mCi}$ $N$-succinimidyl $\left[2,3-{ }^{3} \mathrm{H}\right]$ propionate (sp. act. $249 \mathrm{mCi} / \mathrm{mg}$, Amersham International) essentially after the method of Bolton and Hunter (1973). Excess reagent was reacted for $5 \mathrm{~min}$ with $500 \mu \mathrm{l}$ of $0.2 \mathrm{M}$ glycine in $0.1 \mathrm{M}$ borate buffer ( $\mathrm{pH}$ 8.5). Reaction products were separated by gel filtration chromatography on a Bio-Gel P-6 (Bio-Rad) column $(50 \times 1.0 \mathrm{~cm}$ i.d.), using the buffer for Ultrogel AcA 22 gel filtration described above. The voided protein fraction was concentrated by ultrafiltration (Amicon YM 2 membrane) and its purity checked by SDS-PAGE and rechromatography on Sephacryl S-200 as described above.

In metabolic experiments, incorporation of radiolabel from [ $\left.{ }^{3} \mathrm{H}\right] \mathrm{C}$-proteins into lipoprotein $\mathrm{A}^{+}$was assayed $60 \mathrm{~min}$ after simultaneous injection of locusts with a dose of the labelled protein in a volume of $20 \mu \mathrm{l}$ and $10 \mathrm{pmol} \mathrm{AKH}$ in a $10 \mu \mathrm{l}$ volume. Haemolymph samples were fractionated by gel filtration on Ultrogel AcA 22 (column dimensions $100 \times 1.6 \mathrm{~cm} \mathrm{i.d.)} \mathrm{as} \mathrm{described} \mathrm{above.}$

\section{Radioassay}

Aliquots of protein fractions containing tritium were counted by liquid scintillation spectrometry in Emulsifier 299 (Packard) using a Packard Tri-Carb Model 4550 spectrometer and corrected for quenching.

\section{RESULTS}

The amino acid compositions of the lipoprotein fractions and total protein fractions $C$ isolated by gel filtration chromatography of Ultrogel AcA 22 of haemolymph from resting locusts $\left(\mathrm{O}, \mathrm{A}_{\text {yellow }}, \mathrm{C}_{\text {rest }}\right)$ or AKH-injected insects $\left(\mathrm{O}_{\mathrm{AKH}}, \mathrm{A}^{+}, \mathrm{C}_{\mathrm{AKH}}\right)$ are shown in Table 1. Obviously, hormone injection leads to a marked change in amino acid composition of the induced lipoprotein fractions as compared with those in the resting situation, e.g. a significant increase in for instance glutamate and alanine and a singificant decrease in glycine, which is accounted for by the contribution of part of the C-protein fraction. From the data of the remaining fraction $\mathrm{C}_{\mathrm{AKH}}$ it is apparent that fraction $\mathrm{C}_{\text {rest }}$ is heterogenous, since its amino acid composition differs appreciably from that of $\mathrm{C}_{\mathrm{AKH}}$.

Chromatography on Sephadex G-75 of the combined B- and C-protein fractions recovered from Ultrogel AcA 22, or direct fractionation of fresh haemolymph samples on Sephacryl S-200 yielded essentially identical results, revealing that protein fraction $C$ is resolved into three fractions $\left(C_{1}-C_{3}\right)$, 
Table 1. Amino acid composition (in mol \%) of haemolymph lipoprotein fractions* and protein fraction $\mathrm{C}^{*}$ isolated from resting and AKH-injected locusts

\begin{tabular}{lrrrrrr}
\hline $\begin{array}{c}\text { Amino } \\
\text { acid }\end{array}$ & \multicolumn{1}{c}{$\mathrm{O}$} & \multicolumn{1}{c}{$\mathrm{A}_{\text {yellow }}$} & \multicolumn{1}{c}{$\mathrm{O}_{\text {AKH }}$} & $\mathrm{A}^{+}$ & $\mathrm{C}_{\text {rest }}$ & $\mathrm{C}_{\text {AKH }}$ \\
\hline Asp & 12.3 & 12.2 & 12.1 & 12.2 & 12.0 & 13.5 \\
Thr & 6.0 & 5.8 & 6.1 & 6.2 & 6.4 & 6.0 \\
Ser & 7.2 & 6.9 & 6.5 & 6.1 & 7.5 & 9.4 \\
Glu & 12.0 & 11.9 & 15.8 & 15.4 & 17.5 & 11.3 \\
Pro & 5.1 & 4.9 & 3.9 & 3.9 & 4.0 & 5.6 \\
Gly & 6.7 & 6.3 & 4.9 & 4.5 & 5.4 & 8.6 \\
Ala & 7.0 & 7.4 & 10.8 & 12.1 & 15.2 & 10.9 \\
Val & 8.1 & 8.0 & 6.6 & 6.5 & 5.0 & 6.3 \\
l Cys & $\mathrm{ND} \dagger$ & $\mathrm{ND}$ & $\mathrm{ND}$ & $\mathrm{ND}$ & 0.3 & 0.4 \\
Met & $\mathrm{ND}$ & $\mathrm{ND}$ & $\mathrm{ND}$ & $\mathrm{ND}$ & $\mathrm{ND}$ & $\mathrm{ND}$ \\
Ile & 5.2 & 5.6 & 5.0 & 4.9 & 3.8 & 4.3 \\
Leu & 10.4 & 10.9 & 11.1 & 11.0 & 8.9 & 7.5 \\
Tyr & 1.1 & 1.3 & 1.3 & 1.4 & 0.2 & 0.6 \\
Phe & 5.0 & 5.0 & 3.2 & 3.2 & 2.1 & 3.3 \\
Lys & 8.1 & 8.1 & 7.3 & 7.4 & 3.9 & 4.0 \\
His & 2.4 & 2.2 & 3.0 & 3.0 & 5.0 & 4.8 \\
Arg & 3.4 & 3.4 & 2.4 & 2.2 & 1.8 & 3.4 \\
& & & & & & \\
\hline
\end{tabular}

*Hydrolyzed for $24,48,72 \mathrm{hr}$. Labile amino acids extrapolated to zero time. Values are means from three independent analyses; maximum deviation from mean values is $<5 \%$. $\uparrow$ ND-not detectable.

only one of which $\left(\mathrm{C}_{2}\right)$ actually decreases after $\mathrm{AKH}$ injection (Fig. 1). Quantitative data on the concentrations of B- and C-proteins in both resting and elevated haemolymph recovered after Sephadex G-75 chromatography are given in Table 2. Recoveries after Sephacryl S-200 fractionation were usually higher; for protein fraction $\mathrm{C}_{2}$ in resting haemolymph values up to $19 \mathrm{mg} / \mathrm{ml}$ were found (see Fig. 1). In contrast to the other fractions, the $\mathrm{C}_{2}$-fraction, particularly when kept isolated from the other C-proteins, appeared to be rather susceptible to degradation processes. Upon standing at $4^{\circ} \mathrm{C}$ in the dark, an
Table 2. Concentrations of B- and C-protein fractions recovered by gel filtration on Sephadex G-75 of haemolymph from resting and AKH-injected locusts

\begin{tabular}{crc}
\hline Protein fraction & $\begin{array}{c}\text { Rest } \\
(\mathrm{mg})\end{array}$ & $\begin{array}{c}\text { AKH-injected } \\
(\mathrm{mg})\end{array}$ \\
\hline B & $4.2 \pm 0.3$ & $4.1 \pm 0.3$ \\
$\mathrm{C}_{1}$ & $5.0 \pm 0.2$ & $5.0 \pm 0.3$ \\
$\mathrm{C}_{2}$ & $14.4 \pm 0.9$ & $4.0 \pm 0.3$ \\
$\mathrm{C}_{3}$ & $1.0 \pm 0.1$ & $1.0 \pm 0.1$ \\
\hline
\end{tabular}

Values represent the means $\pm \mathrm{SD}$ for $1.0 \mathrm{ml}$ haemolymph samples obtained from three different groups of locusts.

increasing number of protein bands was observed by PAGE within a few days. Addition of $2.5 \mathrm{mM}$ glutathione to the samples was ineffective in preventing degradation; however, inclusion of $10 \mu \mathrm{M}$ of the serine protease inhibitor phenylmethylsulphonyl fluoride (PMSF) completely prevented degradation and was therefore routinely added to $\mathrm{C}_{2}$-proteincontaining chromatography fractions prior to ultrafiltration.

The amino acid composition of fraction $\mathrm{C}_{2}$ is rather different from those of the $\mathrm{C}_{1}$ - and $\mathrm{C}_{3}$ fractions; besides, the decrease in $\mathrm{C}_{2}$-protein concentration induced by injection of AKH does not result in an apparent change in composition (Table 3). It should be remarked that in contrast to the other experimental procedures described, for amino analysis of the $\mathrm{C}_{3}$-fraction the total $\mathrm{C}_{3}$-protein peak was used in view of the low concentration of this fraction in the haemolymph. For fraction $\mathrm{C}_{3_{\mathrm{rest}}}$ this results in some contamination with the dominant fraction $\mathrm{C}_{2 \text { rest }}$ (see Fig. 1).

In Ouchterlony immunodiffusion with antiserum prepared against pure lipoprotein $\mathrm{A}^{+}$, only the $\mathrm{C}_{2}$-fraction gave a single precipitation line (which was
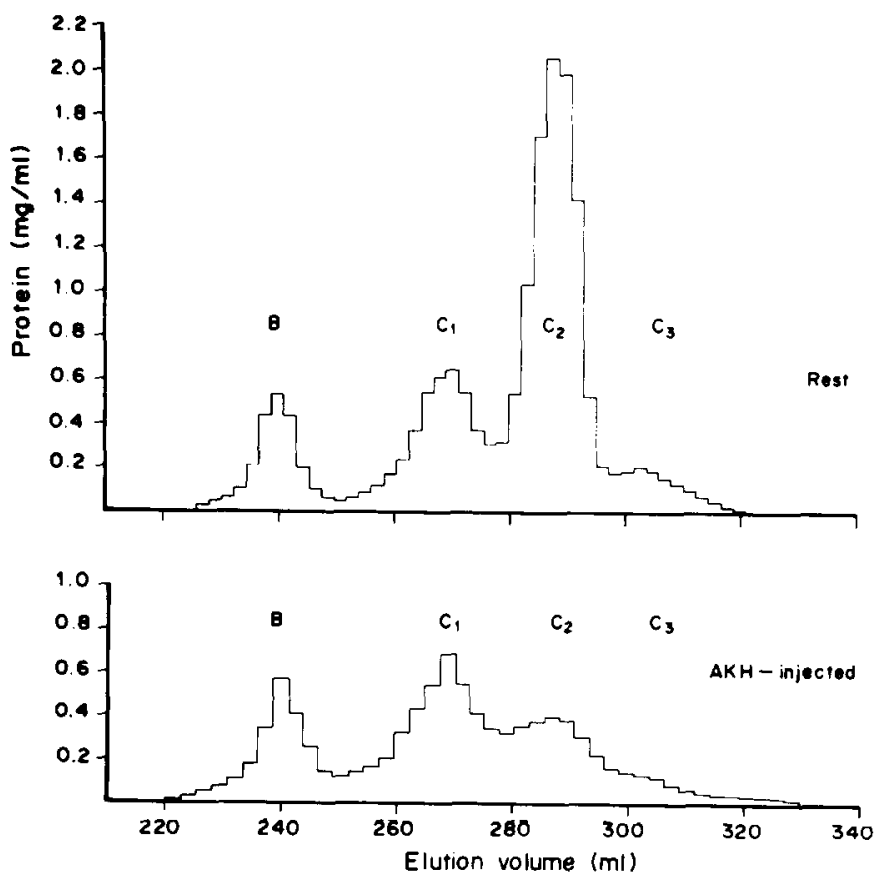

Fig. 1. Elution profiles of locust haemolymph B- and C-protein fractions on Sephacryl S-200. Haemolymph samples $(1.0 \mathrm{ml})$ were taken from resting and $\mathrm{AKH}$-injected locusts. 
Table 3. Amino acid composition (in mol \%) of haemolymph B- and C-protein fractions* from resting and $\mathrm{AKH}$-injected locusts

\begin{tabular}{|c|c|c|c|c|c|c|c|c|}
\hline Amino acid & $\mathbf{B}_{\text {rest }}$ & $\mathrm{B}_{\mathrm{AKH}}$ & $\mathbf{C}_{l_{\text {rest }}}$ & $\mathrm{C}_{1_{\mathrm{AKH}}}$ & $\mathrm{C}_{2 \mathrm{ses} !}$ & $\mathrm{C}_{2 \mathrm{AKH}}$ & $\mathrm{C}_{3 \text { rest }}$ & $\mathrm{C}_{3_{\text {AKKH}}}$ \\
\hline Asp & 13.5 & 13.3 & 10.1 & 9.8 & 12.5 & 12.9 & 12.2 & 11.5 \\
\hline Thr & 4.6 & 4.6 & 4.2 & 4.5 & 6.7 & 6.3 & 7.9 & 9.0 \\
\hline Ser & 6.2 & 6.3 & 12.8 & 12.9 & 6.3 & 6.8 & 9.3 & 9.9 \\
\hline Glu & 10.1 & 10.0 & 12.7 & 12.2 & 20.1 & 19.4 & 10.8 & 9.6 \\
\hline Pro & 5.3 & 5.4 & 6.0 & 6.0 & 3.6 & 3.8 & 9.0 & 8.0 \\
\hline Gly & 8.0 & 8.4 & 10.0 & 10.2 & 3.4 & 3.8 & 8.1 & 9.1 \\
\hline Ala & 10.5 & 10.6 & 10.0 & 10.0 & 17.9 & 17.4 & 11.5 & 9.6 \\
\hline Val & 7.6 & 7.2 & 6.5 & 6.3 & 4.7 & 4.8 & 6.7 & 8.0 \\
\hline$\frac{1}{2}$ Cys & 1.1 & 1.3 & 2.5 & 2.6 & 0.2 & 0.2 & NDt & ND \\
\hline Met & 0.4 & 0.4 & ND & ND & $\mathrm{ND}$ & ND & ND & ND \\
\hline Ile & 3.0 & 3.0 & 4.8 & 5.0 & 3.7 & 3.8 & 4.1 & 5.2 \\
\hline Leu & 10.9 & 11.0 & 7.2 & 7.3 & 110 & 10.9 & 6.4 & 5.8 \\
\hline Tyr & 3.4 & 3.5 & 2.7 & 2.7 & 0.3 & 0.4 & 0.9 & 0.9 \\
\hline Phe & 3.1 & 3.1 & 3.8 & 3.9 & 1.3 & 1.6 & 3.3 & 4.0 \\
\hline Lys & 5.7 & 5.5 & 2.0 & 2.0 & 3.2 & 3.0 & 2.7 & 2.6 \\
\hline His & 2.1 & 2.0 & 1.4 & 1.4 & 4.1 & 3.9 & 5.0 & 4.3 \\
\hline Arg & 4.5 & 4.3 & 3.3 & 3.3 & 1.0 & 1.1 & 2.1 & 2.5 \\
\hline
\end{tabular}

*Hydrolyzed for 24,48 and $72 \mathrm{hr}$. Labile amino acids extrapolated to zero time. Values are means from three independent analyses; maximum deviation from mean values is $\angle 5 \%$.

$+N D-$ not detectable.

also revealed when the total protein fraction $\mathrm{C}$ was used, see Van der Horst et al., 1981a) whereas the antibody cross-reacted neither with the $\mathrm{C}_{1}$-proteins nor with the $\mathrm{C}_{3}$-fraction (results not shown).

Molecular weights of the B- and C-protein fractions were estimated after calibration of both the Sephadex G-75 and Sephacryl S-200 columns with protein standards of known molecular weights (Boehringer Combithek calibration proteins for chromatography), yielding identical results. The molecular weight of fraction $\mathrm{B}$ was about 73,000 , whereas for the C-proteins values of $45,000\left(C_{1}\right), 33,000\left(C_{2}\right)$ and 25,000 $\left(\mathrm{C}_{3}\right)$ were calculated (Fig. 2).

PAGE of the B- and C-protein fractions obtained by Sephacryl S-200 gel filtration of $1.0 \mathrm{ml}$ haemolymph samples from resting and AKH-injected locusts revealed that in contrast to the other $\mathrm{C}$ protein fractions, the $\mathrm{C}_{2}$-protein consists of only one protein band. Apart from a quantitative change in protein $\mathrm{C}_{2}$, no obvious changes in the $\mathrm{C}$-proteins are observed (Fig. 3).

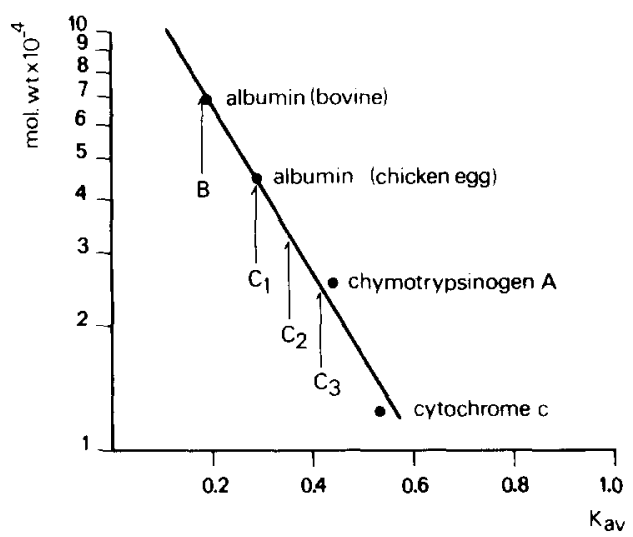

Fig. 2. Molecular weight determination of locust haemolymph B- and C-protein fractions by gel filtration on Sephacryl S-200. Calibration curve was obtained using protein standards. Molecular weights are: bovine albumin 68,000; chicken egg albumin 45,000; chymotrypsinogen $A$ 25,000 ; cytochrome $c 12,500$.
SDS-PAGE demonstrates that protein fraction $\mathrm{C}_{2}$ consists of only one subunit (Fig. 4), which is also present in the elevated haemolymph lipoprotein fractions $\left(\mathrm{O}_{\mathrm{AKH}}, \mathrm{A}^{+}\right)$in contrast to the lipoproteins in the resting situation $\left(O, A_{\text {yellow }}\right)$ in which such a subunit is absent. Molecular weight of the $\mathrm{C}_{2}$-polypeptide chain is about 20,000 (Fig. 5). All lipoprotein fractions contain a subunit of about mol. wt 77,000 apart from a very heavy one (mol. wt over 200,000 ). The subunit from protein B has a mol. wt of about 74,000 , the major polypeptide chains of $\mathrm{C}_{1}$ are mol. wt 54,000 and mol.wt 39,$000 ; C_{3}$ contains only one major subunit with an identical mol. wt as $\mathrm{C}_{2}$ (Figs 4 and 5).

The obvious discrepancy in molecular weight of the $\mathrm{C}_{2}$-protein estimated by gel filtration chromatography $(33,000)$ and the value obtained by SDS-PAGE $(20,000)$ prompted us to assay this fraction for carbohydrate. Indeed, $\mathrm{C}_{2}$ appeared to be a glycoprotein; carbohydrate content amounted to $12.5 \pm 1.2 \%$ (mean \pm SD of four analyses).

Preliminary studies on the dynamies of ${ }^{3} \mathrm{H}$-labelled $\mathrm{C}_{2}$-protein in which a fixed incubation time $(60 \mathrm{~min})$ was used are illustrated in Fig. 6. Groups of 20 locusts were injected each with $20 \mu \mathrm{l}$ aliquots of $\left[{ }^{3} \mathrm{H}\right] \mathrm{C}_{2}$-protein (containing $248,000 \mathrm{dpm}$ ) along with $10 \mathrm{pmol} \mathrm{AKH}$ in a $10 \mu \mathrm{l}$ vol. After $60 \mathrm{~min}$, haemolymph was collected and pooled samples fractionated by gel filtration on Ultrogel AcA 22. Both the $\mathrm{A}^{+}$ lipoprotein fraction formed and, to a lesser extent, $\mathrm{O}_{\mathrm{AKH}}$ appeared to contain radiolabel (Fig. 6). When, by way of control, similar experiments were repeated with $\left[{ }^{3} \mathrm{H}\right] \mathrm{C}_{1}$-protein prepared in the same way and containing $238,000 \mathrm{dpm}$ per $20 \mu \mathrm{l}$, no incorporation of radiolabel into lipoprotein fractions was detected (data not shown).

\section{DISCUSSION}

Though a number of insect species, particularly belonging to Lepidoptera and Orthoptera, are known to rely on lipid oxidation to sustain prolonged flight (for reviews see Gilbert and Chino, 1974; Beenakkers et al., 1981b, 1984a, b), the functioning of the lipoprotein system transporting lipids in the haemolymph 


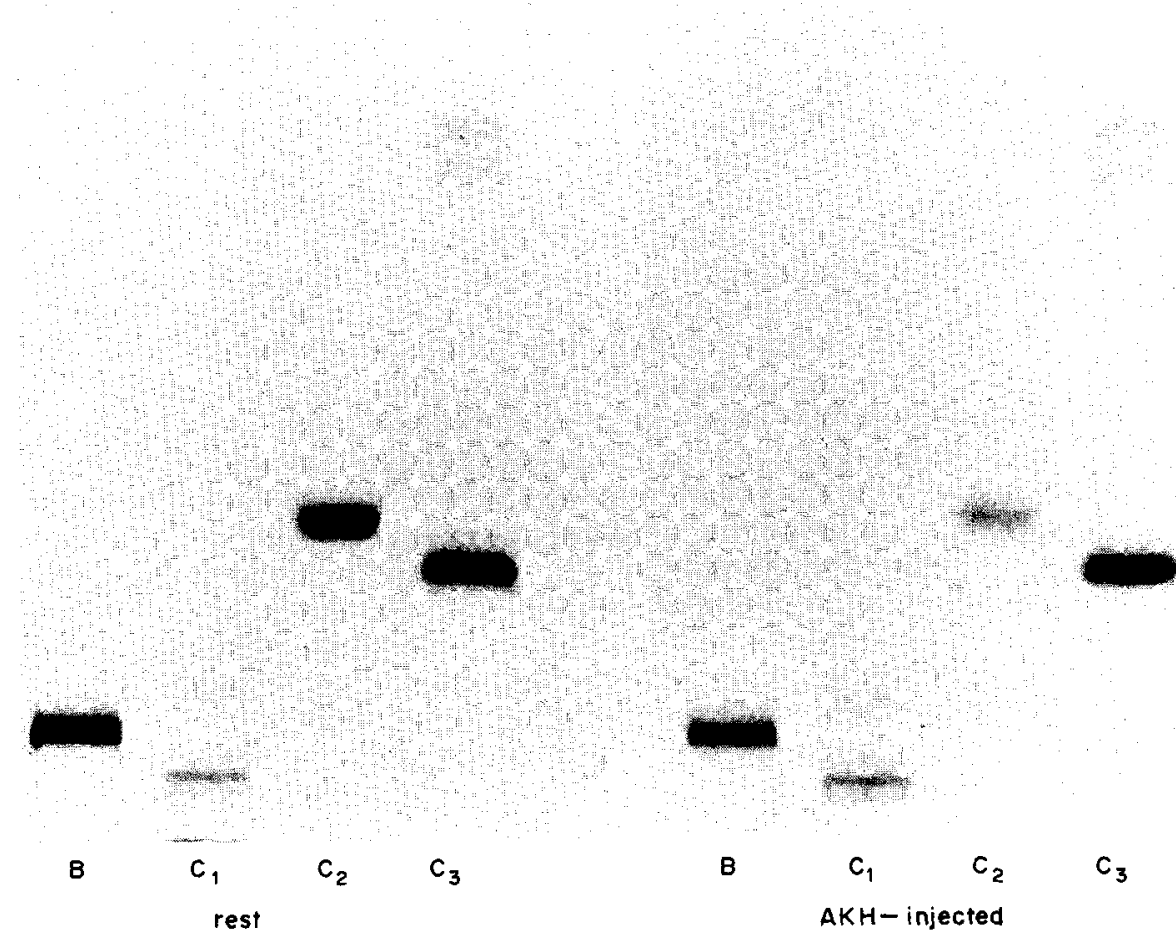

Fig. 3. Polyacrylamide gel electrophoresis (PAGE) in 7.5\% gels of haemolymph B- and C-protein fractions obtained by Sephacryl S-200 gel filtration of $1.0 \mathrm{ml}$ haemolymph from resting and AKH-injected locusts. Proteins were stained with Amido black $10 \mathrm{~B}$.

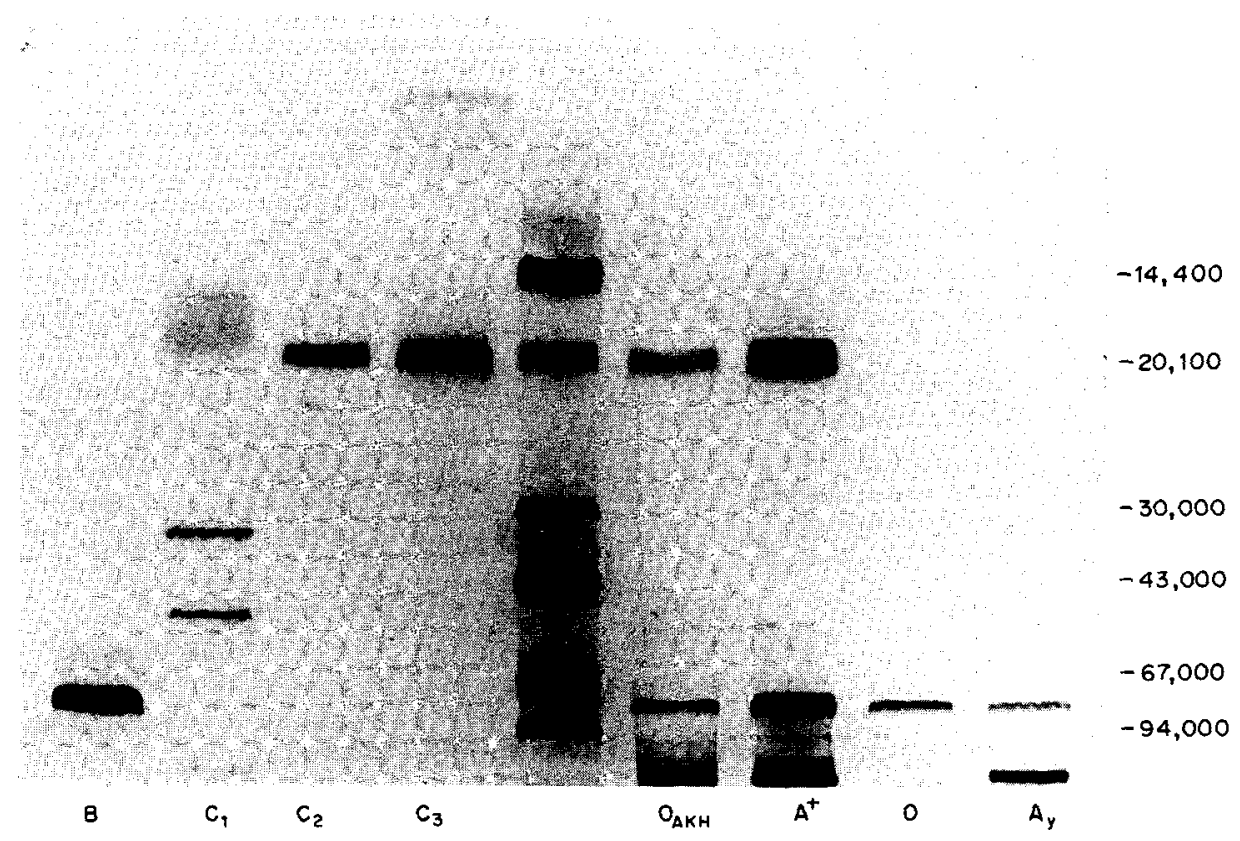

Fig. 4. SDS-polyacrylamide gel electrophoresis (PAGE) in $12.5 \%$ gels of haemolymph protein and lipoprotein fractions obtained from resting and AKH-injected locusts. In the middle lane, a reference sample of protein standards of known molecular weights (see Fig. 5) was run. Gels were stained for protein with Amido black $10 \mathrm{~B}$. 



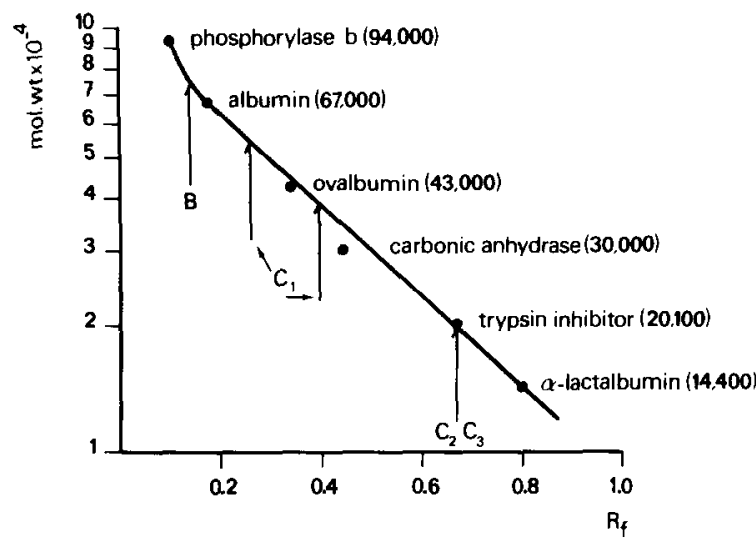

Fig. 5. Molecular weight determination of locust haemolymph B- and C-protein subunits by SDS-polyacrylamide gel electrophoresis (SDS-PAGE) in $12.5 \%$ gels. Calibration curve was obtained using protein standards of known molecular weight (Electrophoresis Calibration Kit; Pharmacia).

has been studied extensively only in the locust. In Locusta migratoria, several lines of evidence indicate that formation of lipoprotein $\mathrm{A}^{+}$results from a rearrangement of protein originating from both lipoprotein $\mathrm{A}_{\text {yellow }}$ and the non-lipid carrying protein fraction $C$; the same mechanism holds for the elevation of the voided lipoprotein fraction $\mathrm{O}$ (Van der Horst et al., 1981a, b). In contrast, most of the lipid originates from the increased release of diacylglycerol from the fat body, though some diacylglycerol is contributed by $A_{\text {yellow }}$ (Van der Horst et al., 1981b). An association of $\mathrm{C}$-fraction proteins with lipoprotein $\mathrm{A}^{+}$has been confirmed recently using ${ }^{3} \mathrm{H}$-labelled preparations of fraction $\mathrm{C}$ (Wheeler and
Goldsworthy, 1983a). Lipoprotein $\mathrm{A}^{+}$apparently is the specific transport protein for the supply of diacylglycerol to the working flight muscles as evidenced in locust half-thorax preparations (Robinson and Goldsworthy, 1977) as well as in flying insects after [ ${ }^{125}$ I]lipoprotein injection (Van der Horst, Storm, Van Doorn and Beenakkers, to be published). The function of the chylomicron-like fraction $\mathrm{O}$ and the elevation of this fraction after AKH-injection (including the participation of protein fraction $\mathrm{C}$ ) remains the subject of further study.

From the present results it is concluded that only one specific protein component $\left(\mathrm{C}_{2}\right)$ of the $\mathrm{C}$-fraction participates in the lipoprotein reorganizations. This $\mathrm{C}_{2}$-protein is the sole protein fraction decreasing in concentration during $\mathrm{A}^{+}$-formation as induced by injection of AKH (Figs 1 and 3, Table 2). In addition, the protein subunit patterns of the two elevated lipoprotein fractions $\left(\mathrm{A}^{+}\right.$and $\left.\mathrm{O}_{\mathrm{AKH}}\right)$ reveal the presence of a subunit with an identical molecular weight as that of the $\mathrm{C}_{2}$-protein (Fig. 4). The changes in amino acid composition of the lipoprotein fractions $\mathrm{A}^{+}$and $\mathrm{O}_{\mathrm{AKH}}$ by comparison with the compositions of the resting lipoprotein fractions $A_{\text {yellow }}$ and $O$, indicative of the contribution of the specific amino acid composition of the $C_{2}$-protein (Tables 1 and 3), give further support, as does the immunoreactivity of the $\mathrm{C}_{2}$-component with antiserum prepared against pure lipoprotein $\mathrm{A}^{+}$(data not shown). Furthermore, in vivo pilot studies on the dynamics of $\mathrm{C}_{2}$-protein using $\left[{ }^{3} \mathrm{H}\right]$ protein $\mathrm{C}_{2}$ showed the incorporation of radiolabel into both elevated lipoprotein fractions (Fig. 6), whereas in contrast $\left[{ }^{3} \mathrm{H}\right]$ protein $\mathrm{C}_{1}$ was not incorporated. Though the principal subunit of the $\mathrm{C}_{3}$-fraction has the same molecular weight as $\mathrm{C}_{2}$-protein (Figs 4 and 5), both the very low level of

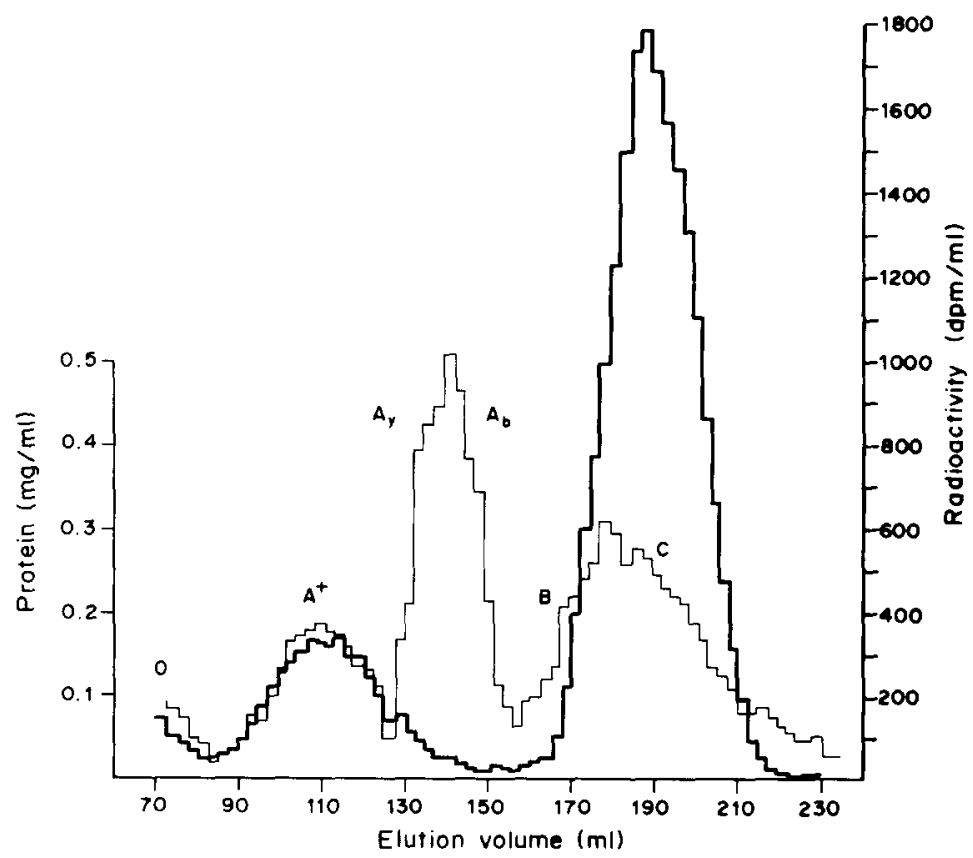

Fig. 6. Distribution of radiolabel over (lipo)protein fractions after gel filtration of $0.7 \mathrm{ml}$ haemolymph on Ultrogel AcA 22. Haemolymph was collected from locusts $60 \mathrm{~min}$ after simultaneous injection of $\left[{ }^{3} \mathrm{H}^{2} \mathrm{C}_{2^{-}}\right.$ protein and $10 \mathrm{pmol}$ AKH. Light lines represent protein concentration; heavy lines represent radioactivity. 
$\mathrm{C}_{3}$-protein in the haemolymph which is unaffected by hormone injection (Figs 1 and 3, Table 2) and its amino acid composition which is markedly different from that of $\mathrm{C}_{2}$-protein render any contribution of $\mathrm{C}_{3}$-protein to the lipoprotein rearrangements unlikely. The absence of immunoreactivity of the $\mathrm{C}_{3}$-proteins with specific antiserum raised against lipoprotein $\mathrm{A}^{+}$(data not shown) confirms this conclusion.

Considering the subunit structure of the locust haemolymph protein fractions studied $\left(\mathrm{B}, \mathrm{C}_{1}-\mathrm{C}_{3}\right)$, protein $B$ apparently contains one subunit, the molecular weight of which determined by SDS-PAGE is estimated as 74,000 while by gel filtration chromatography a nearly identical value $(73,000)$ was obtained for the native protein (Figs 2 and 4). Protein fraction $C_{1}$ apparently is composed of two proteins which are not resolved by gel filtration, since molecular weights of the two most prominent subunits in SDS-PAGE are 54,000 and 39,000 (Fig. 4), whereas by gel filtration a molecular weight of 45,000 was obtained (Fig. 2). Very recently, gel filtration of the $\mathrm{C}_{1}$-fraction on Bio-Gel P-200 (Bio-Rad) resulted in the separation of both proteins, revealing the presence of a predominating component with a mol. wt of 39,000 and only a minor component with a mol. wt of 54,000 (unpublished results). Protein fraction $C_{3}$ consists of only one subunit (mol. wt about 20,000); by gel filtration an approximate value of 25,000 was estimated (Figs 2 and 4). Molecular weight of protein $\mathrm{C}_{2}$ as determined by gel filtration $(33,00)$ deviates appreciably from the single protein subunit molecular weight obtained by SDS-PAGE $(20,000)$ (Figs 2 and 4). However, the $\mathrm{C}_{2}$-component appeared to contain about $12.5 \%$ carbohydrate and the molecular weight of glycoproteins may be overestimated by gel filtration chromatography since, due to a greater hydration in solution induced by the carbohydrate units, they have a more expanded structure than proteins not containing carbohydrate (Spiro, 1973; Aldaheff, 1978). Though migration of glycoproteins in SDS-PAGE may be also anomalous at low gel concentrations $(5 \%)$, at high acrylamide concentrations $(10-12.5 \%)$ as used in the present experiments migrations close to those expected from the molecular mass are observed (Segrest et al., 1971). Therefore, we conclude that the $\mathrm{C}_{2}$-glycoprotein is composed of one single polypeptide chain with an approximate mol. wt of 20,000 . The complex sugar composition of glycoprotein $\mathrm{C}_{2}$ will be published together with the sugar compositions of the lipoprotein fractions (Abbink, Van der Horst, Van Doorn and Beenakkers, in preparation).

As to the protein subunit structure of the lipoprotein fractions, apart from the $C_{2}$-subunit in the elevated lipoprotein fractions $\mathrm{A}^{+}$and $\mathrm{O}_{\mathrm{AKH}}$, all lipoprotein fractions contain a subunit with a mol. wt of about 77,000 (Fig. 4). Besides, a heavy chain subunit of over 200,000 is revealed to which the molecular weight due to its minimal migration is difficult to assess. For locust lipophorin, which we have called lipoprotein $\mathrm{A}_{\text {yellow }}$, a subunit of about 85,000 has been reported apart from a component of about 240,000 which was considered to be an artificially aggregated product of the 85,000 subunit (Gellissen and Emmerich, 1980; Gellissen and Wyatt, 1981). However,
Chino and Kitazawa (1981) also identified both a light-chain $(85,000)$ subunit and a heavy-chain $(250,000)$ subunit in locust lipophorin, but demonstrated that in contrast to the light chain, the heavychain subunit is associated with carbohydrates, rendering an unphysiological aggregation of light-chain subunits to the heavy chain less likely.

Though the present metabolic pilot studies with radiolabelled glycoprotein $C_{2}$, in which a fixed time of $60 \mathrm{~min}$ after injection of locusts with both $\left[{ }^{3} \mathrm{H}\right]$ protein $\mathrm{C}_{2}$ and $\mathrm{AKH}$ was used, indicate the incorporation of $\mathrm{C}_{2}$ into protein $\mathrm{A}^{+}$(as well as $\mathrm{O}_{\mathrm{AKH}}$ ) (Fig. 6), the mechanism of $\mathrm{A}^{+}$-formation is not yet clear. It has been shown recently that injection of a ${ }^{3} \mathrm{H}$-labelled preparation of the total protein fraction $\mathrm{C}$ into locusts in which lipoprotein fraction $\mathrm{A}^{+}$was already present in the haemolymph, resulted in a very rapid association of radiolabel with $\mathrm{A}^{+}$, thus suggesting a competition for binding sites at the surface of lipoprotein $\mathrm{A}^{+}$, which was supported by in vitro studies (Wheeler and Goldsworthy, 1983a). Besides, injection of a preparation of ${ }^{3} \mathrm{H}$-labelled lipoprotein $\mathrm{A}^{+}$into locusts in which the endogenous titre of $\mathrm{A}^{+}$ was decreasing resulted in the recovery of considerably more radiolabel in protein fraction $C$ than in lipoprotein $\mathrm{A}_{\text {yellow. }}$ Therefore, latter authors suggested lipoprotein $\mathbf{A}_{\text {yellow }}$ to be vital for the structural integrity of lipoprotein $\mathrm{A}^{+}$while $\mathrm{C}$-proteins may play only a relatively minor structural role. However, in other work studying the time course in $\mathrm{A}^{+}$-formation, it was argued that lipoprotein $\mathrm{A}_{\text {yellow }}$ does not contribute to $\mathrm{A}^{+}$until some 15-20 min after hormone injection whilst $\mathrm{A}^{+}$is formed without a delay, as is the association of radiolabel from injected $\left[{ }^{3} \mathrm{H}\right]$ protein fraction $\mathrm{C}$ with $\mathrm{A}^{+}$(Wheeler and Goldsworthy, 1983b). Very recently, in vitro incubation studies using locust fat body preparations and isolated haemolymph protein fractions have demonstrated that both lipoprotein fraction $\mathrm{A}_{\text {yellow }}$ and protein fraction $C$ are required for the formation of lipoprotein $\mathrm{A}^{+}$whereas individual fractions were ineffective (Van Heusden et al., 1984). Interestingly, when only lipoprotein $A_{\text {yellow }}$ was present in the medium, AKH failed to stimulate any lipid release from the fat body.

The net result of the mutual interactions between lipoprotein $\mathrm{A}_{\text {yellow}}$, protein $\mathrm{C}_{2}$, and diacylglycerol released from the fat body, being that lipids are efficiently delivered to the contracting flight muscles, will be allowed by the structural features of insect lipoproteins which apparently differ from those of mammalian serum lipoproteins (see Pattnaik et al., 1979; Van der Horst, 1983). The rationale for the involvement of protein $\mathrm{C}_{2}$ is not yet clear though a few explanations have been advanced, including some specific interaction with the flight muscles (Van der Horst, 1983; Wheeler and Goldsworthy, 1983a) possibly resulting in activation of flight muscle lipoprotein lipase (Wheeler et al., 1984), which would resemble the activation of mammalian lipoprotein lipase by apoproteins (for reviews, see Cryer, 1981; Sparrow and Gotto, 1982). In this respect it is of interest that protein $\mathrm{C}_{2}$ is a glycoprotein; it is, therefore, tempting to speculate that one of the functions of the sugars included in mammalian proteins, namely determinants of protein recognition by its 
target cells (for a review, see Olden et al., 1982) is applicable to the locust as well. This possibility is presently under investigation. In contrast to the other C-protein fractions, the isolated $\mathrm{C}_{2}$-protein appeared to be rather susceptible to degradation. As the inclusion of the serine protease inhibitor PMSF completely prevented this degradation, this effect apparently must be due to protease activity. Interestingly, plasma serine proteases co-isolate with human very low density lipoproteins (VLDL) which specifically degrade apolipoprotein $\mathrm{E}$ and therefore cause a loss of ability to interact with the receptor-mediated uptake of VLDL by human skin fibroblasts (Bradley et al., 1982). This protease activity which affects VLDL structure and biological activity was also inhibited by PMSF. It remains, however, to be established whether this breakdown serves a functional role in regulation of receptor interaction; a similar suggestion may be proposed for the locust lipoprotein-bound $\mathrm{C}_{2}$-protein.

\section{REFERENCES}

Aldaheff J. A. (1978) Gel filtration of sialogycoproteins. Biochem. J. 173, 315-319.

Beenakkers A. M. Th., Van der Horst D. J. and Van Marrewijk W. J. A. (1981a) Metabolism during locust flight. Comp. Biochem. Physiol. 69B, 315-321.

Beenakkers A. M. Th., Van der Horst D. J. and Van Marrewijk W. J. A. (1981b) Role of lipids in energy metabolism. In Energy Metabolism and its Regulation in Insects (Edited by Downer R. G. H.), pp. 53-100. Plenum Press, New York.

Beenakkers A. M. Th., Van der Horst D. J. and Van Marrewijk W. J. A. (1984a) Biochemical processes directed to flight muscle metabolism. In Comprehensive Insect Physiology, Biochemistry and Pharmacology (Edited by Kerkut G. A. and Gilbert L. I.), Vol. 10, Chap. 13. Pergamon Press, Oxford.

Beenakkers A. M. Th., Van der Horst D. J. and Van Marrewijk W. J. A. (1984b) Insect flight muscle metabolism. Insect Biochem. 14, 243-260.

Benson J. V., Gordon M. J. and Patterson J. A. (1967) Accelerated chromatographic analysis of amino acids in physiological fluids containing glutamine and asparagine. Analyt. Biochem. 18, 228-240.

Bligh E. G. and Dyer W. J. (1959) A rapid method of total lipid extraction and purification. Can. J. Biochem. Physiol. 37, 911-917.

Bolton A. E. and Hunter W. M. (1973) The labelling of proteins to high specific radioactivities by conjugation to a $\left[{ }^{125} \mathrm{I}\right]$-containing acylating agent. Application to the radioimmunoassay. Biochem. $J$. 133, 529-538.

Bradford M. M. (1976) A rapid and sensitive method for the quantification of microgram quantities of protein utilizing the principle of protein-dye binding. Analyt. Biochem. 72, 248-254.

Bradley W. A., Gilliam E. B., Gotto A. M., Jr and Gianturco S. H. (1982) Apoliprotein-E degradation in human very low density lipoproteins by plasma protease(s): chemical and biological consequences. Biochem. biophys. Res. Commun. 109, 1360-1367.

Chino H. and Kitazawa K. (1981) Diacylglycerol-carrying lipoprotein of hemolymph of the locust and some insects. J. Lipid Res. 22, 1042-1052.

Cryer A. (1981) Tissue lipoprotein lipase activity and its action in lipoprotein metabolism. Int. J. Biochem. 13, $525-541$.

Dubois M., Gilles K. A., Hamilton J. K., Rebers P. A. and Smith F. (1956) Colorimetric method for determination of sugars and related substances. Analyt. Chem. 28, 350-356.
Gellissen G. and Emmerich H. (1980) Purification and properties of a diglyceride-binding lipoprotein (LP I) of the hemolymph of adult male Locusta migratoria. $J$. comp. Physiol. 136, $1-9$.

Gellissen G. and Wyatt G. R. (1981) Production of lipophorin in the fat body of adult Locusta migratoria: comparison with vitellogenin. Can. J. Biochem. 59, $645-456$.

Gilbert L. I. and Chino H. (1974) Transport of lipids in insects. J. Lipid Res. 15, 439-456.

Laemmli U. K. and Favre M. (1973) Nutrition of the head of bacteriophage T4. J. mol. Biol. 80, 575-599.

Mwangi R. W. and Goldsworthy G. J. (1977) Diglyceridetransporting lipoproteins in Locusta. J. comp. Physiol. 114, 177-190.

Olden K., Parent J. B. and White S. L. (1982) Carbohydrate moieties of glycoproteins: a re-evaluation of their function. Biochim. biophys. Acta 650, 209-232.

Pattnaik N. M., Mundall E. C., Trambusti B. G., Law J. H. and Kézdy F. J. (1979) Isolation and characterization of a larval lipoprotein from the hemolymph of Manduca sexta. Comp. Biochem. Physiol. 63B, 469476.

Robinson N. L. and Goldsworthy G. J. (1977) Adipokinetic hormone and the regulation of carbohydrate and lipid metabolism in a working flight muscle preparation. $J$. Insect Physiol. 23, 9-16.

Schacterle G. R. and Pollack R. L. (1973) A simplified method for the quantitative assay of small amounts of protein in biological materials. Analyt. Biochem. 51, $654-655$.

Segrest J. P., Jackson R. L., Andrews E. P. and Marchesi V. T. (1971) Human erythrocyte membrane glycoprotein: a re-evaluation of the molecular weight as determined by SDS polyacrylamide gel electrophoresis. Biochem. biophys. Res. Commun. 44, 390-395.

Shore V. and Shore B. (1962) The protein subunit of human serum lipoproteins of density $1.125-1.200 \mathrm{gram} / \mathrm{ml}$. Biochem. biophys. Res. Commun. 9, 455-460.

Sparrow J. T. and Gotto A. M. Jr (1982) Apoprotein/lipid interactions: studies with synthetic polypeptides. $C R C$ crit. Rev. Biochem. 13, 87-107.

Spiro R. G. (1973) Glycoproteins. Adv. Protein Chem. 17, 349-367.

Van der Horst D. J. (1983) Lipid transport in insects. In Metabolic Aspects of Lipid Nutrition in Insects (Edited by Mittler T. E. and Dadd R. H.), pp. 183-202. Westview Press, Boulder, Colorado.

Van der Horst D. J., Baljet A. M. C., Beenakkers A. M. Th. and Van Handel E. (1978) Turnover of locust haemolymph diglycerides during flight and rest. Insect Biochem. 8, 369-373.

Van der Horst D. J., Van Doorn J. M. and Beenakkers A. M. Th. (1979) Effects of the adipokinetic hormone on the release and turnover of haemolymph diglycerides and on the formation of the diglyceride-transporting lipoprotein system during locust flight. Insect Biochem. 9, 627-635.

Van der Horst D. J., Stoppie P., Huybrechts R., De Loof A. and Beenakkers A. M. Th. (1981a) Immunological relationships between the diacylglycerol-transporting lipoproteins in the haemolymph of Locusta. Comp. Biochem. Physiol. 70B, 387-392.

Van der Horst D. J., Van Doorn J. M., De Keijzer A. N. and Beenakkers A. M. Th. (1981b) Interconversions of diacylglycerol-transporting lipoproteins in the haemolymph of Locusta migratoria. Insect Biochem. 11, 717-723.

Van Heusden M. C., Van der Horst D. J. and Beenakkers A. M. Th. (1984) In vitro studies on hormone-stimulated lipid mobilization from fat body and interconversion of haemolymph lipoproteins of Locusta migratoria. J. Insect Physiol. In press. 
Wheeler C. H. and Goldsworthy G. J. (1983a) Proteinlipoprotein interactions in the haemolymph of Locusta during the action of adipokinetic hormone: the role of $\mathrm{C}_{\mathrm{L}}$-proteins. J. Insect Physiol. 29, 349-354.

Wheeler C. H. and Goldsworthy G. J. (1983b) Qualitative and quantitative changes in Locusta haemolymph pro- teins and lipoproteins during ageing and adipokinetic hormone action. J. Insect Physiol. 29, 339-347.

Wheeler C. H., Van der Horst D. J. and Beenakkers A. M. Th. (1984) Lipolytic activity in the flight muscles of Locusta migratoria measured with haemolymph lipoproteins as substrates. Insect Biochem. 14, 261-266. 